\title{
Exotic Pumpkinseed Sunfish Lepomis gibbosus (Linnaeus, 1758) in the International Minho River (Iberian Peninsula), and Parasitic Association with Myzobdella lugubris Leidy, 1851 (Annelida, Hirudinea)
}

\author{
Ana Lages ${ }^{1 *}$, Dimítri de Araújo Costa ${ }^{1,2}$, Nuno Gomes ${ }^{1,2}$ and Carlos Antunes ${ }^{1,2}$ \\ ${ }^{1}$ Aquamuseu do Rio Minho, Parque do Castelinho, Portugal \\ ${ }^{2}$ Interdisciplinary Centre of Marine and Environmental Research (CIIMAR), University of Porto, Estuarine Ecology and Biological Invasions Group \\ (EEBI), Portugal
}

Submission: April 20, 2021; Published: June 08, 2021

Corresponding author: Ana Lages, Aquamuseu do Rio Minho, Parque do Castelinho, 4920-290 Vila Nova de Cerveira, Portugal

\begin{abstract}
To evaluate the establishment of the emerged species Lepomis gibbosus (Linnaeus, 1758) in the international section of the Minho River (Iberian Peninsula) the abundance was analysed for 7 years. This study also describes the world's first record of parasitism between the leech Myzobdella lugubris Leidy, 1851 and L. gibbosus. The earliest record of species L. gibbosus, also known as pumpkinseed sunfish, was in the Spanish area of the Minho River basin, in the beginning of the 2000s. It is considered an established species in the estuary, due to its ecological release capacity, which has been increasing over the last few years. Physical condition, age, feeding patterns, and reproduction habits were analysed from July 2014 to October 2015. Individuals sampled appear in a good physical condition (b>3). The oldest individual captured was 4 years old, with $\mathrm{L}_{\max }=18.6 \mathrm{~cm}$. Females have a higher gonadosomatic investment than males $\left(\mathrm{F}_{1: 585}=150.43\right.$, $\left.\mathrm{p}<0.01\right)$, particularly in July ( $\mathrm{F}=7.39 \%$; $\mathrm{M}=1.4 \%)$, which comply with the values of the hepatosomatic index $\left(\mathrm{F}_{2: 300}=34.23, \mathrm{p}<0.01\right)$. Breeding season occurs between July/August and sexual maturity is reached at age of 1 . Regarding the feeding regime, 18 taxa were identified from gut content. In the first year of life, the pumpkinseed has a preference for insects and crustaceans. In adult age, gastropods are the preference, which can cause trophic competition with native species. Therefore, monitoring studies should continue to follow the population dynamics.
\end{abstract}

Keywords: North Atlantic; Pumpkinseed; Aquatic Ecology; Fyke Nets; Interspecific Relationship; Leech

\section{Introduction}

In nature, ecosystems are dynamic environments that have evolved over billions of years to reach the actual natural barriers that surround them [1]. However, direct, and indirect anthropogenic impacts can lead to local and global changes by breaking those barriers, and provoking changes in modern species distribution. The spread of invasive species is the main cause of serious disturbances, instigating harmful effects on natural ecosystems worldwide and is one of the main reasons for local biodiversity loss, particularly in aquatic ecosystems [2,3]. Furthermore, the introduction of new pathological organisms (e.g., via associated parasitic species) and 'genetic actuation' (e.g., hybridization and introgression) are other impacts that may affect the native species [4].

The River Minho is in the Iberian Peninsula and its international section separates North Portugal from South Galicia (Spain), over the last $75 \mathrm{~km}$ of the $300 \mathrm{~km}$ of total length [5]. According to the Portuguese Environment Agency, the Minho River is considered to have good water quality [6]. The ichthyofauna is composed of 50 species [7], and some of them are classified under Natura 2000 Minho River site including diadromous fishes: sea trout (Salmo trutta Linnaeus, 1758), allis shad (Alosa alosa (Linnaeus, 1758), twaite shad (Alosa falax (Lacepède, 1803), sea 
lamprey (Petromyzon marinus Linnaeus, 1758); and freshwater, such as the panjorca (Achondrostoma arcasii (Steindachner, 1866) and Northern straight mouth nase (Pseudochondrostoma duriense (Coelho, 1985). Despite its ecological and local economic importance, the introduction of non-native species is believed to be one of the main causes for the decrease in local biodiversity [8].

The pumpkinseed sunfish Lepomis gibbosus (Linnaeus, 1758) is natural from North America, and it was introduced in Europe in 1880 where it had a huge expansion in several countries, accompanying the introduction of other species via sport fishing and as an ornamental species, in the aquariums [9]. The earliest record of Lepomis gibbosus on the Iberian Peninsula was between 1910-1913, identified at Lake Banyoles, northern Spain. In Portugal, it was first recorded in 1977 in the Guadiana River [10]. The introduction of this species on the Iberian Peninsula would have occurred accidentally, at a similar time as the insertion of the largemouth black bass, known as Micropterus salmoides (Lacepède, 1802) [9]. Other examples of accidental introduction of the pumpkinseed sunfish identified in Europe, which also coincided with the introduction of the common carp (Cyprinus carpio Linnaeus, 1758), includes England and Czech Republic [9].

In the Minho River, under the Natura Miño-Minho project (INTERREG 0234_Miño_Minho_1_E), pumpkinseed has been detected in Spanish dams in the early 2000s, while in the Minho River estuary the capture of one specimen was recorded in 2007 [8,11]. This study, therefore, aims to perform the first characterization of the species L. gibbosus in the international Minho River section and to assess the impacts it may cause on established native species. Additionally, association parasitic with the leech ectoparasitic species Myzobdella lugubris Leidy, 1851 is described for the first time in Europe, as well as on a global scale.

\section{Material and Methods}

\section{Study Area}

The Minho River is located in the located in the NW-Iberian Peninsula (SW Europe; Figure 1) and extends approximately 300 $\mathrm{km}$ to the Atlantic Ocean. The last $70 \mathrm{~km}$ serve as a northwestern border between Portugal and Spain. The tidal influence extends until $40 \mathrm{~km}$ upstream comprising the estuarine area of approximately $23 \mathrm{Km}^{2}$, however, saltwater intrusion reaches only the first $25 \mathrm{~km}$ [8]. River flow varies seasonally: the maximum flow $\left(2500 \mathrm{~m}^{3} \cdot \mathrm{s}^{-1}\right)$ is associated with periods of intense precipitation in the winter/early spring, and the minimum flow $\left(60 \mathrm{~m}^{3} \cdot \mathrm{s}^{-1}\right)$ occurs in the summer/early autumn, associated with periods of drought [12]. The international section of the Minho River is classified as a Natura 2000 site due to its ecological importance.

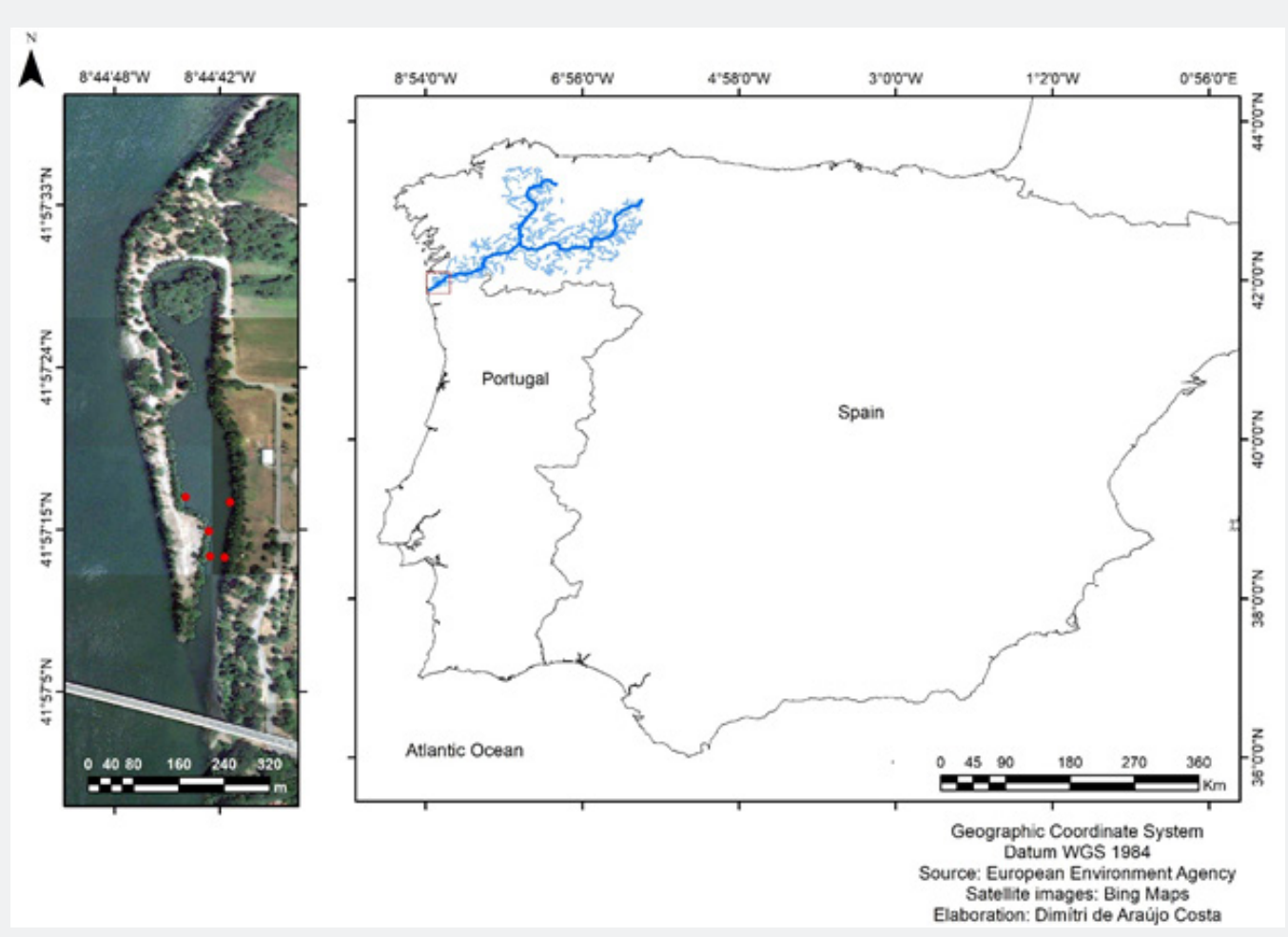

Figure 1: Map of Minho River location on the Iberian Peninsula, signaling the study area Marina da Lenta, in Vila Nova de Cerveira.

The Minho estuary, comprises mesotidal characteristics, where the average tidal variation oscillates at approximately 4 and extends between the municipalities of Caminha to Valença, meters of amplitude. Similarly, saline concentrations varies with 
the tides and can reach approximately 35 ups. During the summer months, the temperature of the water can reach approximately $21^{\circ} \mathrm{C}$ and $9^{\circ} \mathrm{C}$ in the winter. In general, the waters of River Minho are considered of good quality [13]. Samplings were performed at Marina da Lenta in the estuarine and international zone of Minho River, with the followings coordinates GPS points: N41ํ5'13.17"

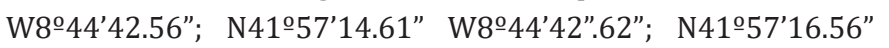

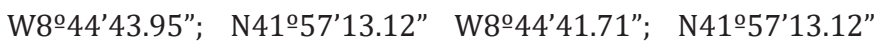
W8ㄴ4'41.71" (Figure 1).

For taxonomic research, Lepomis gibbosus specimens were collected from the March 3, 31, 2021, on international river Minho

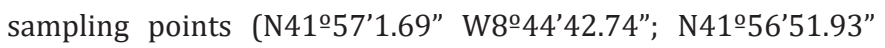
W8044'42.59"; N4157'14.21" W844'59.35”), using fyke nets anchored from 1-4 m depth. Abiotic data was collected with an Aquaread $^{\mathrm{TM}}$ Aquameter GPS. M. lugubris specimens were photographed in detail with Nikon Digital Sight D5-L1 camera and Nikon SMZ800 stereomicroscope and photographed while associated with Lepomis gibbosus. Some individuals for both species were deposited at the Natural History Museum of the Iberian Peninsula (NatMIP - "Museu de História Natural da Península Ibérica"), Aquamuseu do Rio Minho, Vila Nova de Cerveira, Portugal.

\section{Sampling Strategy}

Sampling took place between January 2013 and September 2019 and the more species-specific data, such as physiological indices, feeding regime and age analysis comprised samples obtained from July 2014 until August 2015, using five fyke nets (10 mm mesh, $7 \mathrm{~m}$ in length with two openings in funnel shape) in Marina da Lenta, checked twice a week. In each sample taken, water parameters were recorded (temperature, $\mathrm{pH}$, salinity, depth, and conductivity), with a YSI 6820 multiparameter probe (USA).

\section{Data collection}

All captured individuals were measured for total length (TL) and fork length (FL) $(0.1 \mathrm{~cm})$ and weighed $(0.01 \mathrm{~g})$. Stomach contents were collected and subsequently analysed, according to the Knoöpell [14] methodology. After the evisceration and scrutinized through the magnifying glass, each prey item was identifying to the lowest taxonomic level possible, gathering all in seven groups: Crustacea, Monogononta, Mollusca, Insect, Arachnida, Fish and Vegetation [15-17]. After the extraction, otoliths were washed in $70 \%$ alcohol to remove organic matter [18]. To a proper age analysis, the option followed was the staining technique [19]. Otoliths were placed in gelatin capsules, correctly identified with paper strips, and then filled with resin (Resin EpoThin No. 20-8140 and the catalyst EpoThin No.20.8142, with the proportion 100:39, respectively).

After $9 \mathrm{~h}$ drying, a transversal axis cut was made in the capsule and glued on a slide [20]. Posteriorly, each side of the capsule was softly polished and stained with toluidine blue (1\%) for one hour. To finish the process, the capsule was washed with clean water
[21] and EDTA acid was applied for five minutes. To better support the age analysis, scales were also used to read rings, according to Regier [22]. Scales were collected from every individual, with different sizes, and washed with $\mathrm{KOH} 5 \%$, to remove all the exceeding organic matter. Next step, using a magnifying glass, scales with the focus well defined were selected and measured (software Cell^ $\mathrm{b}$ - Basic Research imaging software - Olympus).

\section{Data analysis}

Abundance was expressed in CPUE (catch per unit effort) represented by the CPUE=n/e/t, where $n$ is the number of individuals captured by fyke nets, e is the number of fyke nets used and $t$ is the unit of time. Using gonads and liver weight, the gonadosomatic index (GSI = gonad weight $(\mathrm{g}) /$ body weight $(\mathrm{g}) \mathrm{x}$ 100) [23] and hepatosomatic (HSI = liver weight (g) / body weight (g)) [24], respectively, serving as indicators of the reproductive season [25]. The length-weight equation $\mathrm{W}=\mathrm{a} \mathrm{L}^{\mathrm{b}}$ was used to estimate the relationship between the weight $(\mathrm{g})$ of the fish and its total length $(\mathrm{cm})$. Using the linear regression of the logtransformed equation: $\log (\mathrm{W})=\log (\mathrm{a})+\mathrm{b} \log (\mathrm{L})$, the parameters $a$ and $b$ were calculated with a representing the intercept and $b$ the slope of the relationship.

The value of $b$ may deviate from the 3 that represents an isometric growth due to environmental features or fish condition [26]. Prey items were quantified using the relative frequency of occurrence of each food item and expressed as the percentage occurrence of all food organism [27]. Prior to the statistical analyses, normality and homoscedasticity tests were applied, using Shapiro-Wilk and Levene, respectively. Differences between groups were assessed through a distribution-free analysis of variance (One-Way, ANOVA), (Student's t-tests, Two-Sample), (Test $\mathrm{X}^{2}$ ) using the STATISTICA software, version 8.0 [28]. Variations of physical condition and gender ratio were tested to verify any differences, performing the non-parametric Kruskal-Wallis test.

\section{Results}

\section{Abundance}

Abundance of L. gibbosus is expressed in CPUE values, from 2013 until September 2019. During this period, a total of 48319 individuals were caught. No individuals were captured between January 2013 and June 2013 and the first catch of this species occurred in July of this year. Since then, catches increased over time, with similar values in $2015\left(\max _{\text {CPUE }}=3.7\right)$ and 2016 $\left(\max _{\mathrm{CPUE}}=4.2\right)$. But in 2017, CPUE values fourfold, reaching the highest recorded value of 17.8 in November 2017. In October 2018, the CPUE value registered was 32.8, almost double of 2017, and in 2019, the highest value of CPUE was observed in July, with 35.9. The temperature was expressed over the same period, with the maximum values of CPUE coincided with the elevated temperatures, reached between May and September, especially in July with the maximum value of $24.6^{\circ} \mathrm{C}$. Winter months showed low CPUE values as temperatures decrease to approximately $9^{\circ} \mathrm{C}$ (Figure 2). 


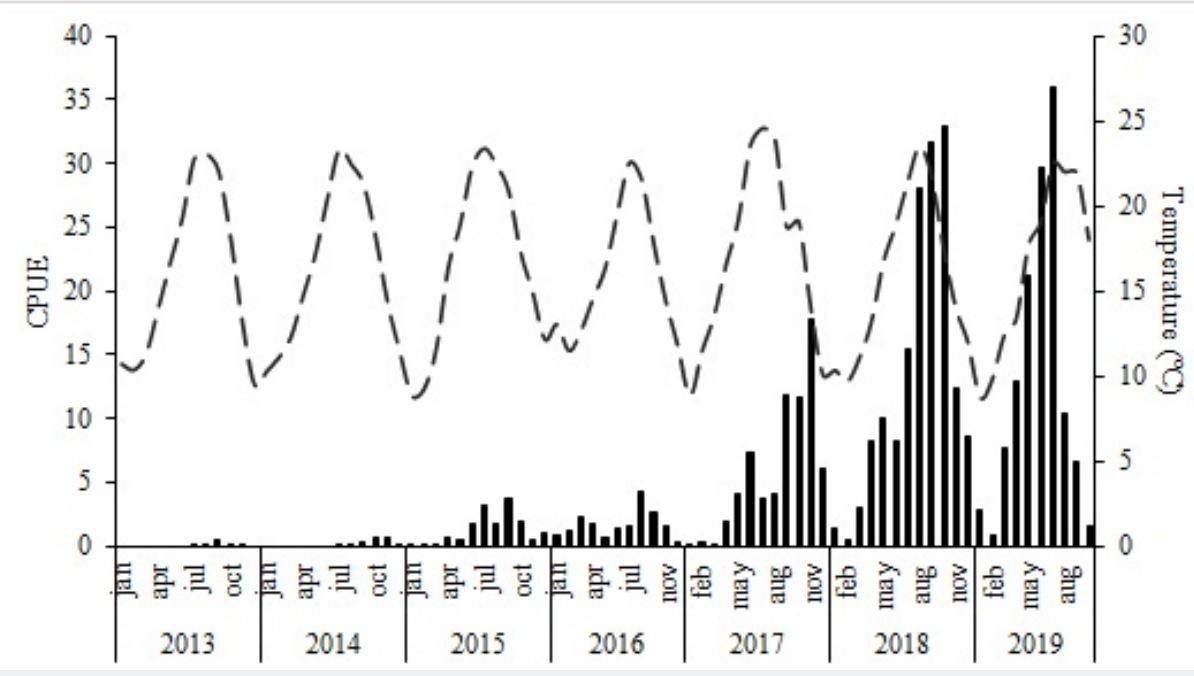

Figure 2: Abundance values represented in CPUE (amount of individuals/number of fyke nets/ number of days) for $L$. gibbosus and temperature $\left({ }^{\circ} \mathrm{C}\right)$ between 2013 and 2019, in the Minho River.

The abiotic factors registered between 2014 and 2015 are expressed through PCA in Figure 3. According to graphical analysis, temperature, and transparency (Secchi) were the most driving factors, explaining the months distribution, with a clear dissimilarity between summer ones (May, June, July, August, and September) and the winter period (from November 2014 to March 2015). The highest values of transparency were recorded between
November and January 2015, with the highest value in December $(3.1 \pm 0.67 \mathrm{~m})$. The highest values for temperature were recorded in June, July, and August, above $22^{\circ} \mathrm{C}$. The lowest temperature was recorded in January $2015\left(8.86 \pm 0.65^{\circ} \mathrm{C}\right)$. Simultaneously, in July 2014 , the highest mean values of salinity $(0.08 \pm 0.03$ ups $)$ and the highest mean values of conductivity $(0.18 \pm 0.07 \mathrm{mS} / \mathrm{cm})$ were observed.

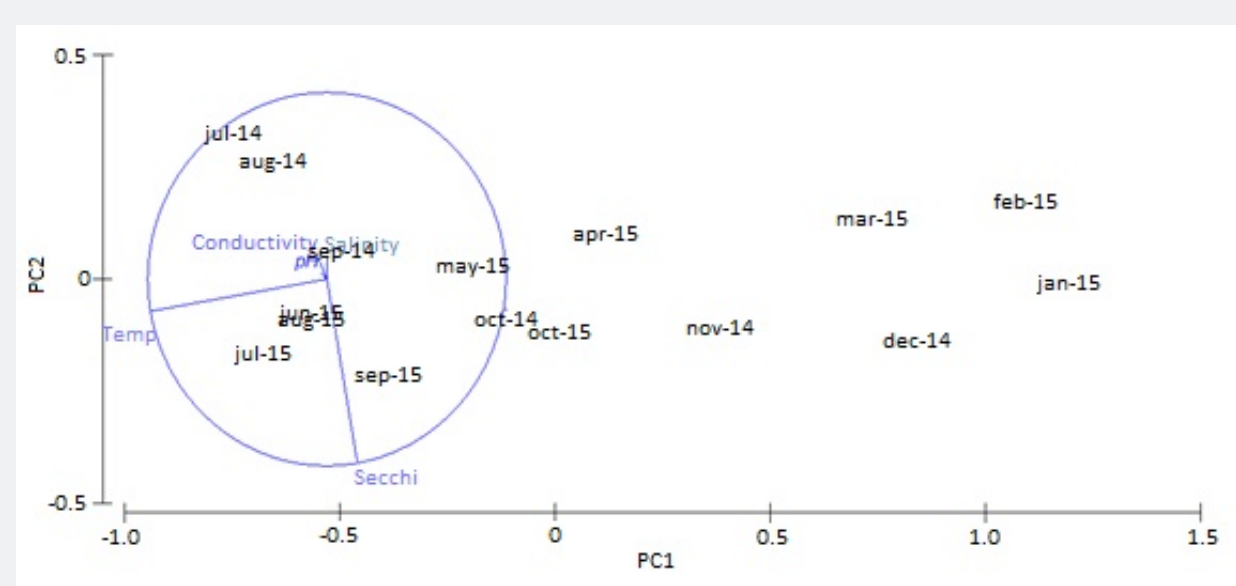

Figure 3: Principal Component Analyses (PCA) among environmental parameters, during 2014 and 2015.

Table 1 indicates the medium length values recorded over the seven years. The year 2015 showed the greatest rise in length with a minimum value recorded in January of $4.5 \mathrm{~cm}$, reaching the maximum value of $12 \mathrm{~cm}$ in November. Similarly in 2016, the medium values also show an increase between $10.2 \mathrm{~cm}$ and $12.1 \mathrm{~cm}$, which is significantly higher compared to previous years (2013 and 2014). After 2017, medium length value ranges increase, with a minimum value of $8.1 \mathrm{~cm}$ and a maximum of 12.1 $\mathrm{cm}$. For the last two years of the study (2018 and 2019), medium values stabilized, demonstrating lengths ranging between 6 to 9 cm. Remarkably in 2019, medium values were almost all recorded around $9 \mathrm{~cm}$.

\section{Physical Condition}

The relationship between weight-length was calculated based on the data collected from measurements taken in 2013 until 2019, of a total of 12562 individuals from the River Minho (Figure 4). L. gibbosus population presented a minimum length of 2.6 $\mathrm{cm}$ and $0.3 \mathrm{~g}$ in September 2016, while the maximum individual registered had $18.6 \mathrm{~cm}$ and $124 \mathrm{~g}$ in January 2016. Through the 
allometric condition factor, the value of the regression coefficient (b) was calculated from the weight-length ratio. In general, the pumpkinseed sunfish population shows a value of $b>3$, which indicates positive allometric growth. For each year, from 2013 to 2019 , the values of the regression coefficient (b) are presented in Table 2, always showing $b$ values superior to 3 . The year with the lowest value was in 2016, with $b=3.10$, and the highest value was reached in 2018 and 2019, with b=3.21. Between 2013 and 2019, condition factor $\mathrm{K}$ was calculated. The lowest value was in 2014 $(\mathrm{K}=1.58)$ and the highest was in $2015(\mathrm{~K}=1.83)$ (Figure 5).

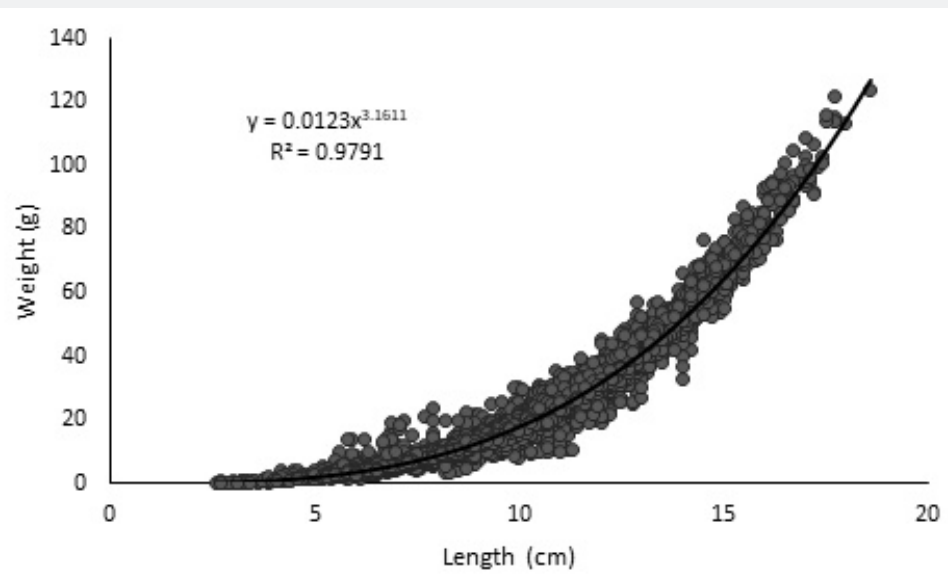

Figure 4: Weight-Length ratio of pumpkinseed population, captured in Minho River, during the period between 2013 until 2019. The allometric equation is given as: $Y=$ Total weight $(\mathrm{g}), \mathrm{X}=$ Total Length $(\mathrm{cm}), \mathrm{a}=0.0123$ and $\mathrm{b}=3.1611$.

Table 1: L. gibbosus population medium values $( \pm$ SD) of length $(\mathrm{cm})$, captured between 2013 and 2019, in the river Minho.

\begin{tabular}{|c|c|c|c|c|c|c|c|}
\hline \multirow{2}{*}{ Months } & \multicolumn{7}{|c|}{ Years } \\
\hline & 2013 & 2014 & 2015 & 2016 & 2017 & 2018 & 2019 \\
\hline Jan & & & $4.5 \pm 0(\mathrm{~N}=1)$ & $\begin{array}{c}11.7 \pm 1.0 \\
(\mathrm{~N}=108)\end{array}$ & $\begin{array}{c}9.3 \pm 1.5 \\
(N=6)\end{array}$ & $\begin{array}{l}7.1 \pm 2.6 \\
(N=157)\end{array}$ & $\begin{array}{c}9 \pm 1.7 \\
(N=257)\end{array}$ \\
\hline $\mathrm{Feb}$ & & & $5.2 \pm 0(\mathrm{~N}=1)$ & $\begin{array}{c}11.9 \pm 1.4 \\
(\mathrm{~N}=203)\end{array}$ & $\begin{array}{c}12.1 \pm 3.3 \\
(\mathrm{~N}=24)\end{array}$ & $\begin{array}{c}6.6 \pm 2.8 \\
(\mathrm{~N}=47)\end{array}$ & $\begin{array}{c}8.3 \pm 1.6 \\
(\mathrm{~N}=97)\end{array}$ \\
\hline Mar & & & $5.8 \pm 1.7(\mathrm{~N}=13)$ & $\begin{array}{c}12.1 \pm 7.4 \\
(\mathrm{~N}=374)\end{array}$ & $\begin{array}{c}11.9 \pm 2.8 \\
(\mathrm{~N}=29)\end{array}$ & $\begin{array}{l}6.2 \pm 1.8 \\
(N=214)\end{array}$ & $\begin{array}{l}9.1 \pm 1.8 \\
(\mathrm{~N}=221)\end{array}$ \\
\hline Apr & & & $5.5 \pm 0.8(\mathrm{~N}=72)$ & $\begin{array}{c}11.1 \pm 1.1 \\
(N=220)\end{array}$ & $\begin{array}{c}10.5 \pm 3.2 \\
(\mathrm{~N}=187)\end{array}$ & $\begin{array}{l}6.7 \pm 2.4 \\
(N=267)\end{array}$ & $\begin{array}{l}9.2 \pm 1.9 \\
(\mathrm{~N}=386)\end{array}$ \\
\hline May & & & $6.7 \pm 1.3(\mathrm{~N}=50)$ & $\begin{array}{c}11.4 \pm 1.3 \\
(\mathrm{~N}=83)\end{array}$ & $\begin{array}{c}11.3 \pm 3.1 \\
(N=473)\end{array}$ & $\begin{array}{l}8.3 \pm 2.8 \\
(N=228)\end{array}$ & $\begin{array}{l}9.5 \pm 1.7 \\
(N=344)\end{array}$ \\
\hline Jun & $\begin{array}{c}5.6 \pm 0.6 \\
(\mathrm{~N}=2)\end{array}$ & & $\begin{array}{l}8.4 \pm 1.3 \\
(N=179)\end{array}$ & $\begin{array}{c}11.5 \pm 1.3 \\
(N=192)\end{array}$ & $\begin{array}{l}8.7 \pm 4.2 \\
(N=772)\end{array}$ & $\begin{array}{l}9.5 \pm 2.9 \\
(N=303)\end{array}$ & $\begin{array}{l}9.6 \pm 1.4 \\
(N=216)\end{array}$ \\
\hline Jul & $\begin{array}{l}5.4 \pm 1 \\
(\mathrm{~N}=3)\end{array}$ & $\begin{array}{c}10.1 \pm 4 \\
(\mathrm{~N}=2)\end{array}$ & $\begin{array}{c}9.3 \pm 1 \\
(N=408)\end{array}$ & $\begin{array}{c}10.8 \pm 2.1 \\
(N=180)\end{array}$ & $\begin{array}{l}9.4 \pm 2.1 \\
(N=326)\end{array}$ & $\begin{array}{l}9.4 \pm 2.0 \\
(N=259)\end{array}$ & $\begin{array}{l}9.5 \pm 1.3 \\
(\mathrm{~N}=283)\end{array}$ \\
\hline Aug & $\begin{array}{c}8.0 \pm 1.3 \\
(\mathrm{~N}=2)\end{array}$ & $\begin{array}{c}10.7 \pm 3.7 \\
(\mathrm{~N}=10)\end{array}$ & $\begin{array}{l}9.9 \pm 1 \\
(\mathrm{~N}=76)\end{array}$ & & $\begin{array}{c}10.3 \pm 1.7 \\
(\mathrm{~N}=160)\end{array}$ & $\begin{array}{c}9.4 \pm 1.7 \\
(\mathrm{~N}=84)\end{array}$ & $\begin{array}{l}9.1 \pm 1.8 \\
(\mathrm{~N}=171) \\
\end{array}$ \\
\hline Sep & $\begin{array}{c}9.2 \pm 0.8 \\
(\mathrm{~N}=71)\end{array}$ & $\begin{array}{c}6.2 \pm 2.3 \\
(\mathrm{~N}=32)\end{array}$ & $\begin{array}{c}10.7 \pm 1.1 \\
(\mathrm{~N}=466)\end{array}$ & $\begin{array}{l}10.2 \pm 3 \\
(\mathrm{~N}=613) \\
\end{array}$ & & $\begin{array}{l}8.9 \pm 1.3 \\
(\mathrm{~N}=253)\end{array}$ & $\begin{array}{c}9.6 \pm 1.7 \\
(\mathrm{~N}=64)\end{array}$ \\
\hline Oct & $\begin{array}{c}9.6 \pm 1.1 \\
(\mathrm{~N}=15)\end{array}$ & $\begin{array}{c}6.3 \pm 1.6 \\
(\mathrm{~N}=84)\end{array}$ & $\begin{array}{c}11.5 \pm 1.2 \\
(\mathrm{~N}=254)\end{array}$ & $\begin{array}{l}11 \pm 2.8 \\
(\mathrm{~N}=397)\end{array}$ & $\begin{array}{l}9.2 \pm 2.8 \\
(\mathrm{~N}=810)\end{array}$ & $\begin{array}{l}8.9 \pm 1.5 \\
(\mathrm{~N}=343)\end{array}$ & \\
\hline Nov & $\begin{array}{c}9.8 \pm 0.8 \\
(\mathrm{~N}=6)\end{array}$ & $\begin{array}{l}5.9 \pm 1.3 \\
(\mathrm{~N}=105)\end{array}$ & $\begin{array}{l}12 \pm 0.9 \\
(\mathrm{~N}=80)\end{array}$ & $\begin{array}{c}11.3 \pm 2.6 \\
(\mathrm{~N}=218)\end{array}$ & $\begin{array}{l}8.1 \pm 2.8 \\
(N=402)\end{array}$ & $\begin{array}{l}9.1 \pm 1.7 \\
(\mathrm{~N}=352)\end{array}$ & \\
\hline Dec & & $\begin{array}{c}7.8 \pm 3.2 \\
(\mathrm{~N}=6)\end{array}$ & $\begin{array}{l}11.6 \pm 1 \\
(\mathrm{~N}=166)\end{array}$ & $\begin{array}{c}10.5 \pm 2.5 \\
(\mathrm{~N}=42)\end{array}$ & $\begin{array}{c}8.1 \pm 3 \\
(\mathrm{~N}=236)\end{array}$ & $\begin{array}{l}9.1 \pm 1.7 \\
(\mathrm{~N}=268) \\
\end{array}$ & \\
\hline Total & $\begin{array}{c}9.1 \pm 1.2 \\
(\mathrm{~N}=99)\end{array}$ & $\begin{array}{c}6.4 \pm 2 \\
(\mathrm{~N}=239)\end{array}$ & $\begin{array}{c}10 \pm 1.9 \\
(\mathrm{~N}=1766)\end{array}$ & $\begin{array}{l}11.1 \pm 2.2 \\
(\mathrm{~N}=2630)\end{array}$ & $\begin{array}{c}9.3 \pm 2.9 \\
(\mathrm{~N}=3425)\end{array}$ & $\begin{array}{c}8.4 \pm 2.4 \\
(\mathrm{~N}=2775)\end{array}$ & $\begin{array}{l}10.5 \pm 1.7 \\
(N=2039)\end{array}$ \\
\hline
\end{tabular}


Table 2: Regression coefficient values (b) since 2013 to 2019 and the number of individuals per year.

\begin{tabular}{|c|c|c|c|c|c|c|c|c|}
\hline Years & $\mathbf{2 0 1 3}$ & $\mathbf{2 0 1 4}$ & $\mathbf{2 0 1 5}$ & $\mathbf{2 0 1 6}$ & $\mathbf{2 0 1 7}$ & $\mathbf{2 0 1 8}$ & $\mathbf{2 0 1 9}$ & General \\
\hline $\mathrm{b}$ & 3.15 & 3.26 & 3.14 & 3.1 & 3.14 & 3.21 & 3.21 & 3.16 \\
\hline $\mathrm{N}$ & 99 & 239 & 1764 & 2630 & 3021 & 2773 & 2036 & 12562 \\
\hline
\end{tabular}

For this time 1076 individuals (8.6\% of the total data) were analysed regarding their gender, age, and diet, collected between July 2014 and September 2015. Fulton's factor condition was calculated for both genders of L. gibbosus, showing no significant differences between males and females $\left(\mathrm{F}_{1 ; 1042}=2.68 ; \mathrm{p}>0.05\right)$. However, over the sampling period, both females $\left(\mathrm{F}_{12 ; 560}=43.10\right.$; $\mathrm{p}<0.01)$ and males $\left(\mathrm{F}_{13 ; 457}=28.76 ; \mathrm{p}<0.01\right)$ show significant differences. In general, there is a slightly higher $\mathrm{k}$ value in females when compared to males, except for November 2014 and April
2015. The highest values reached for both males and females were in August 2014, with $\mathrm{k}=2.01$ and $\mathrm{k}=2.13$, respectively. The month with the lowest physical condition was in April 2015 for females $(\mathrm{k}=1.43)$ and in December for males $(\mathrm{k}=1.43)$ (Figure 6). For individuals caught in the same months (Aug/2014 to Sep/2015), according to their gender and age ( 0 to 3 ), and considering the data normality, there were no significant differences ( $t$-test $=1.64$; $\mathrm{p}>0.05)$ for physical condition $(1.78 \pm 0.33$ for males and $1.81 \pm$ 0.24 for females) (Table 3).

Table 3: Condition factor between genders and age $(N=$ number of individuals; $S D=$ Standard Deviation; $p=$ level of significance for the Student's T-test).

\begin{tabular}{|c|c|c|c|c|c|c|c|c|}
\hline \multirow{2}{*}{ Age } & \multicolumn{3}{|c|}{ Males } & \multicolumn{3}{|c|}{ Females } & \multirow{2}{*}{$\mathbf{t}$} & \multirow{2}{*}{$\mathbf{p}$} \\
\hline & $\mathbf{N}$ & Mean & SD & $\mathbf{N}$ & Mean & SD & & \\
\hline $0^{+}$ & 143 & 1.52 & 0.12 & 146 & 1.53 & 0.15 & 0.88 & 0.38 \\
\hline $1^{+}$ & 219 & 1.85 & 0.37 & 528 & 1.88 & 0.18 & 1.07 & 0.28 \\
\hline $2^{+}$ & 108 & 1.98 & 0.2 & 117 & 1.98 & 0.19 & 0.23 & 0.82 \\
\hline $3^{+}$ & 1 & 2.1 & & 1 & 2.02 & & & \\
\hline Total & 471 & 1.78 & 0.33 & 573 & 1.81 & 0.24 & 1.64 & 0.1 \\
\hline
\end{tabular}

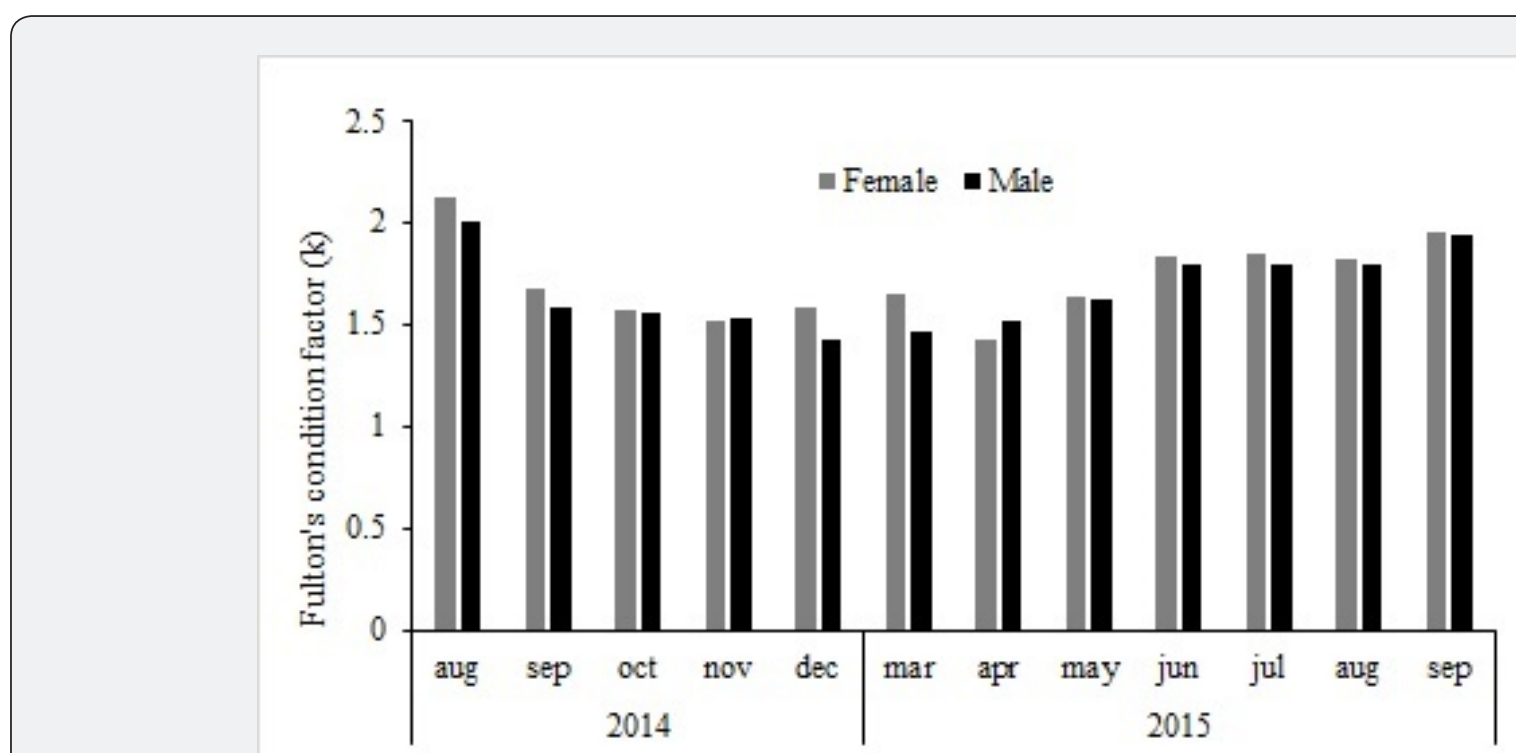

Figure 6: Physical condition for pumpkinseed individuals, for females ( $N=573)$ and males ( $N=470)$, between August 2014 and September 2015.

\section{Gender proportion, GSI and HSI}

Of the 1076 individuals captured, it was only possible to identify the gender in 1044 individuals, of which 573 individuals (54.9\%) were females and 471 individuals (45.1\%) were males (females: males $=1.22: 1$ ). The remaining 32 individuals were juveniles. Over the sampling period, there were significant differences in the proportion of catch between males and females $\left(X^{2}=9.97 ; p=0.002\right)$ (Figure 7). Gonadosomatic index (GSI) was 
calculated in a total of 587 pumpkinseeds females that showed significant differences $\left(\mathrm{F}_{11 ; 317}=35.51 ; \mathrm{p}<0.01\right)$. The highest index was registered in July 2015 (7.39 $\pm 3.6 \%)$, followed by August
$2015(5.98 \pm 2.58 \%)$ and June 2015 (3.2 $\pm 3.2 \%)$. The lowest values were recorded in October $2014(0.47 \pm 0.38 \%)$, January 2015 (0.5\%) and March 2015 (0.7 $\pm 0.31 \%)$.

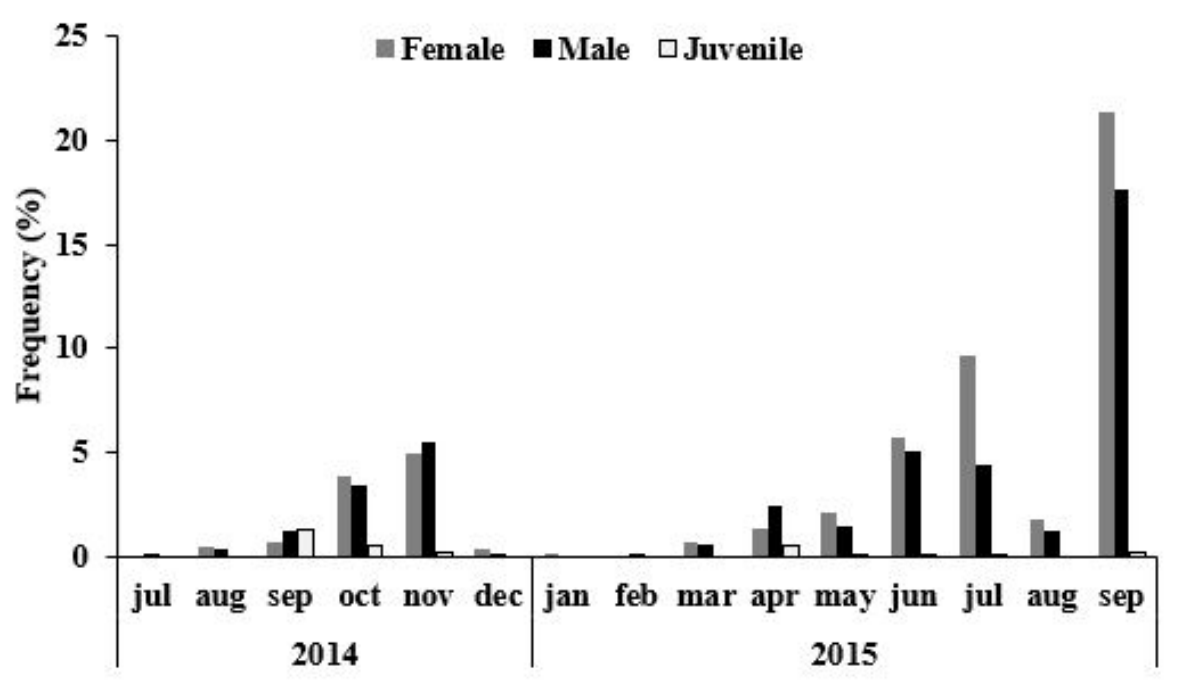

Figure 7: Catches in percentage of females and males of pumpkinseed during July 2014 and September $2015(N=1076)$.

There were no records of captured females in July 2014 and February 2015. For males, there are significant differences in GSI over this period $\left(\mathrm{F}_{11 ; 246}=19.69 ; \mathrm{p}<0.01\right)$, nonetheless these values are still significantly low comparing with GSI of females $\left(\mathrm{F}_{1 ; 585}=150.43 ; \mathrm{p}<0.01\right)$. Between May and July 2015, GSI for males increased, with the maximum value of $1.4 \pm 0.73 \%$, while the lowest values were recorded in November $2014(0.15 \pm 0.09$ $\%$ ), December 2014 (0.16 $\pm 0.05 \%$ ) and October 2014 (0.16 \pm
$0.09 \%$ ). Males were not captured in January 2015 (Figure 8). The hepatosomatic index was calculated for 728 individuals, captured only in 2015, divided into females, males, and juveniles. Females generally have the highest HIS, with a continuous increase from April to August. Throughout 2015, there are significant differences between males, females, and juveniles $\left(\mathrm{F}_{2 ; 300}=34.23 \mathrm{p}<0.01\right)$. Juveniles have a lower HIS in July and September (Figure 9).

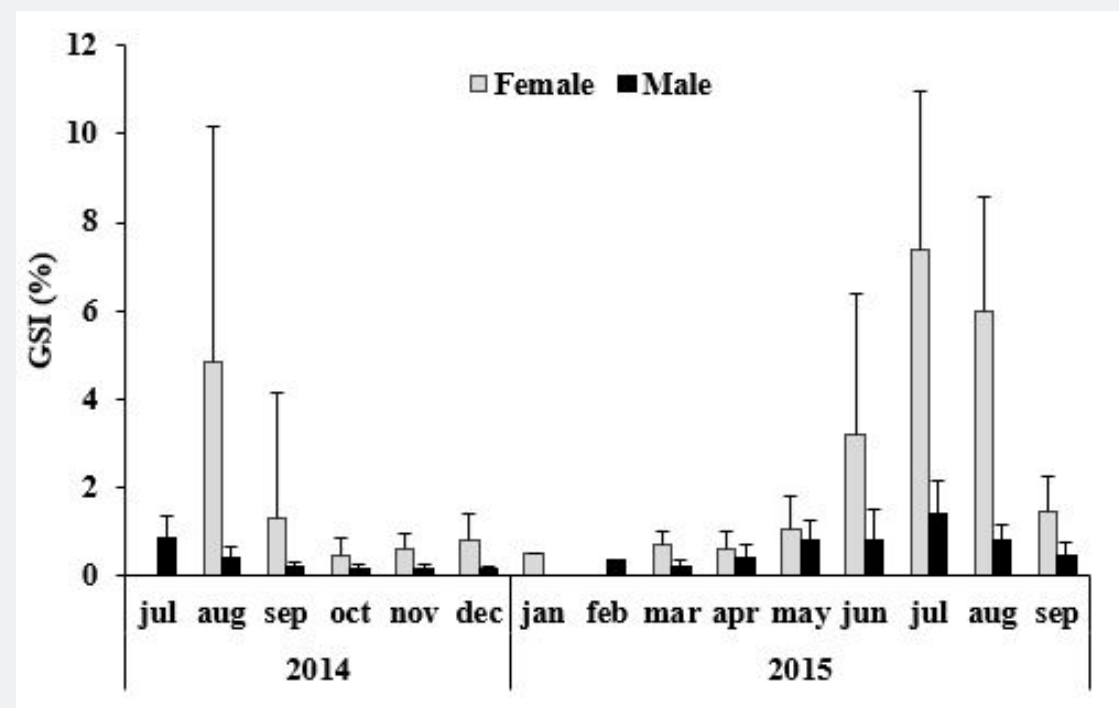

Figure 8: Values of GSI ( \pm SD) for both genders of $L$. gibbosus population ( $F, N=329 ; M, N=258)$, captured between July 2014 and September 2015. 


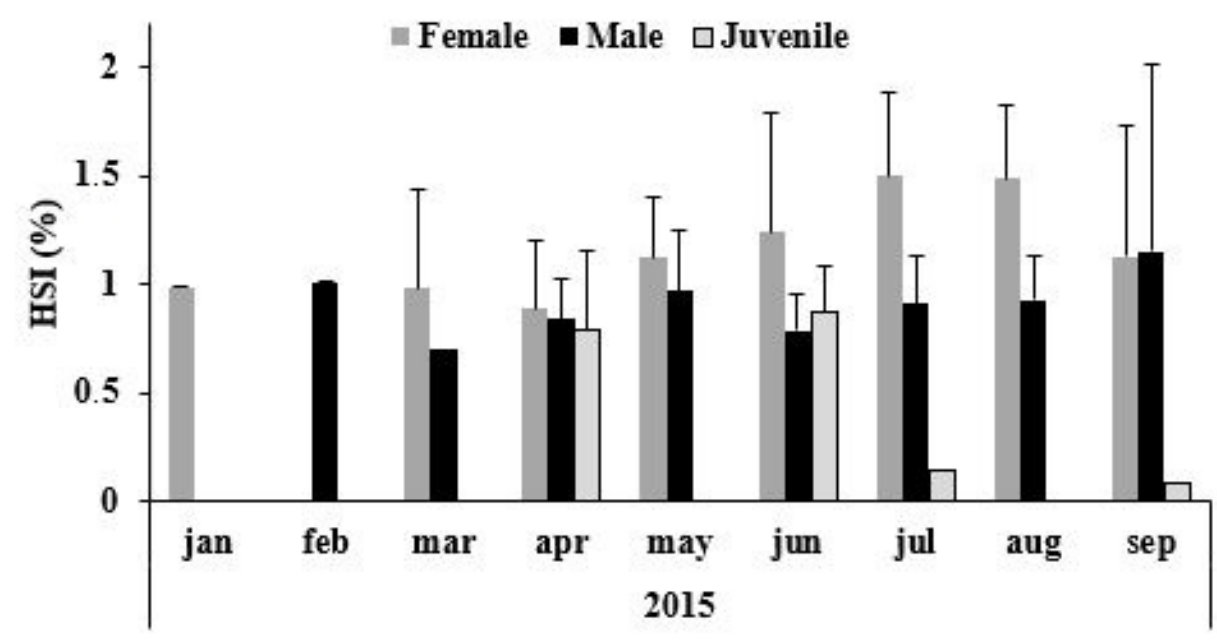

Figure 9: Values of $\mathrm{HSI}( \pm \mathrm{SD})$ for females, males, and juveniles of $L$. gibbosus population ( $\mathrm{F}, \mathrm{Nt}=231 ; \mathrm{M}, \mathrm{Nt}=68 ; \mathrm{J}, \mathrm{Nt}=4)$, captured in 2015.

\section{Age and Growth}

The relation between TL (total length) of pumpkinseed and their age was established essentially through the analysis of scales, expressed in the following equation $\mathrm{y}=3.5744 \mathrm{x}+5.3842\left(\mathrm{R}^{2}=\right.$ 0.6604 ). This analysis considers a total of 147 individuals, caught in 2014 and 2015. Subsequently, age analysis was extrapolated to all individuals from 2013 until 2019, regarding a total of 12562 individuals. Age analysis shows fish aged $0^{+}$have a mean length of $5.9 \mathrm{~cm}$, with a minimum value of $2.6 \mathrm{~cm}$ and a maximum of $6.9 \mathrm{~cm}$. The number of individuals captured with this age is significantly higher in 2017 and 2018. In the first year of life, the mean length is $9 \mathrm{~cm}$, with a minimum value of $7 \mathrm{~cm}$ and a maximum of $10.5 \mathrm{~cm}$. It is possible to observe an increase over time of L. gibbosus, with a maximum of 1485 individuals caught in 2018, with 1 year old.

According to the total number, pumpkinseed with $1^{+}$were the most collected over the years. In the second year, the mean length increased to $11.9 \mathrm{~cm}$, with a minimum value of $14.2 \mathrm{~cm}$ and a maximum of $17.7 \mathrm{~cm}$. The first year of pumpkinseed registered in Minho River, in 2013, there were no individuals of this age, and in 2014 and 2015 the number of captures was still very low. Instead, 2016 and 2017 shows a significant catch of $3^{+}$individuals, reaching a maximum of 220 in 2017. In 2018 and 2019, the captures dropped to 54 and 16, respectively. With an age of $4^{+}$ there were only two captures made, in 2016 with a length of 18.6 $\mathrm{cm}$, and in 2017 in a length of $18 \mathrm{~cm}$ (Table 4).

Table 4: Pumpkinseed individuals age structure in the River Minho, from 2013 to 2019. The number of specimens (N) and de mean of length (X) in $\mathrm{cm}$ are given, as the total number of individuals captures for each age group. Minimum and maximum length values (in $\mathrm{cm}$ ) for each year and age group are given in brackets.

\begin{tabular}{|c|c|c|c|c|c|c|c|c|c|}
\hline \multirow{2}{*}{\multicolumn{2}{|c|}{$\begin{array}{c}\text { Age (Years) } \\
2013\end{array}$}} & \multicolumn{7}{|c|}{ Sampling period } & \multirow{3}{*}{\begin{tabular}{|c|} 
Total \\
5.9
\end{tabular}} \\
\hline & & \multirow{2}{*}{$\frac{2014}{5.5(4.4-6.4)}$} & \multirow{2}{*}{$\frac{2015}{5.6(4-6.9)}$} & \multirow{2}{*}{$\frac{2016}{5.7(4.2-6.9)}$} & \multirow{2}{*}{$\frac{2017}{4.7(2.6-6.9)}$} & \multirow{2}{*}{$\frac{2018}{6.0(3.3-6.9)}$} & \multirow{2}{*}{$\frac{2019}{5.9(2.9-6.9)}$} & \multirow[b]{2}{*}{$6.4(2.7-6.9)$} & \\
\hline \multirow{2}{*}{$0^{+}$} & $X$ & & & & & & & & \\
\hline & $\mathrm{N}$ & 5 & 200 & 140 & 83 & 840 & 849 & 196 & 2313 \\
\hline \multirow{2}{*}{$1^{+}$} & $\mathrm{X}$ & $9.2(7.1-10.5)$ & $8.4(7-10.5)$ & $9.2(7-10.5)$ & $9.2(7-10.5)$ & $8.9(7-10)$ & $8.7(7-10.5)$ & $8.9(7-10.5)$ & 9 \\
\hline & $\mathrm{N}$ & 88 & 21 & 873 & 890 & 1136 & 1485 & 1399 & 5892 \\
\hline \multirow[t]{2}{*}{$2^{+}$} & $\mathrm{x}$ & $\begin{array}{c}11.1(10.7- \\
11.6)\end{array}$ & $\begin{array}{c}12.1(10.7- \\
13.9)\end{array}$ & $\begin{array}{c}11.7(10.6- \\
14)\end{array}$ & $12(10.6-14.1)$ & $\begin{array}{c}11.9(10.6- \\
14.1)\end{array}$ & $12(10.6-14.1)$ & $\begin{array}{c}11.5 \\
(10.6-14) \\
\end{array}$ & 11.9 \\
\hline & $\mathrm{N}$ & 6 & 16 & 747 & 1452 & 824 & 385 & 425 & 3855 \\
\hline \multirow{2}{*}{$3^{+}$} & $\mathrm{X}$ & & $\begin{array}{c}14.6(14.5- \\
14.7)\end{array}$ & $\begin{array}{c}14.9(14.3- \\
15.9)\end{array}$ & $\begin{array}{c}14.8(14.2- \\
16.7)\end{array}$ & $\begin{array}{c}15.3(14.2- \\
17.2)\end{array}$ & $\begin{array}{c}15.6(14.2- \\
17.7)\end{array}$ & $\begin{array}{c}15(14.2- \\
17.5)\end{array}$ & 15.1 \\
\hline & $\mathrm{N}$ & & 2 & 4 & 204 & 220 & 54 & 16 & 500 \\
\hline \multirow{2}{*}{$4^{+}$} & $\mathrm{X}$ & & & & 18.6 & 18 & & & 18.3 \\
\hline & $\mathrm{N}$ & & & & 1 & 1 & & & 2 \\
\hline
\end{tabular}




\section{Diet composition}

Between July 2014 and September 2015 there were 1077 individuals collected, and only 532 were analysed regarding their stomachal content, which 269 (50.6\%) individuals had an empty stomach and 263 (49.4\%) showed traces or entire prey inside, allowing their identification. In total were identified 18 taxonomic groups, being that 216 individuals had preys possible to identify, which are given in Table 5. The most important item is Diptera (44\%) which appears in almost every age group, followed in second by Gastropoda (31.5\%) also the preference in ages of $2^{+}$and $3^{+}$, and in third by Cladocera $(27.8 \%)$, which is highly consumed in age $0^{+}$.

Table 5: Diet composition of Lepomis gibbosus population in river Minho. Values of frequency occurrence (F0) are expressed in percentage, according with the age structure and size-classes.

\begin{tabular}{|c|c|c|c|c|c|c|}
\hline & & & Age ( & & & \\
\hline & 6.9) $(\mathrm{N}=138)$ & $\begin{array}{c}1^{+} \\
(7.0-10.5) \\
(N=71)\end{array}$ & $\begin{array}{c}2^{+} \\
(10.6-14.1)\end{array}$ & $\begin{array}{c}3^{+} \\
(14.2-17.7)\end{array}$ & & Total \\
\hline & Amphipoda & 18.1 & 14.1 & 33.3 & & 16.7 \\
\hline Crustoron & Cyclopoida & 0.8 & & & & 5.1 \\
\hline Crustacea & Cladocera & 41.3 & 4.2 & & & 27.8 \\
\hline & Isopoda & 0.7 & & & & 0.5 \\
\hline Monoconota & Colurella & 2.9 & & & & 1.9 \\
\hline Fivilugorituita & Lepadella & 0.7 & & & & 0.5 \\
\hline Mollusca & Gastropoda & 15.2 & 62 & 50 & & 31.5 \\
\hline & Anisoptera & 0.7 & 8.5 & 16.7 & & 3.7 \\
\hline & Coleoptera & 2.2 & & & & 1.9 \\
\hline & Diptera & 42 & 49.3 & 16.7 & 100 & 44 \\
\hline & Ephemeroptera & 0.7 & & & & 0.5 \\
\hline Insecta & Megaloptera & 0.7 & & & & 0.5 \\
\hline & Plecoptera & 0.7 & & & & 0.5 \\
\hline & Trichoptera & 9.4 & 5.6 & & & 7.9 \\
\hline & Hemiptera & 24.6 & 5.6 & 16.7 & & 18.1 \\
\hline & Zigoptera & 2.9 & 18.3 & 50 & & 9.3 \\
\hline Arachnida & Not identified & 0.7 & & & & 0.5 \\
\hline & Eggs (not identified) & 0.7 & & & & 0.5 \\
\hline Osteichthyes & Larvae (not identified) & 2.9 & 1.4 & & & 2.3 \\
\hline & Adults (not identified) & 1.4 & 8.5 & & & 3.7 \\
\hline Vegetation & & 14.5 & 43.7 & 50 & & 24.5 \\
\hline Not identified & & 13.8 & 1.4 & & & 9.3 \\
\hline
\end{tabular}

\section{Taxonomic Approach and Parasitic Association}

Phylum Chordata Haeckel, 1874

SubPhylum Vertebrata Lamarck, 1801

InfraPhylum Gnathostomata Gegenbaur 1874

SuperClass Pisces Linnaeus, 1758

ClassActinopterygii Klein, 1885

Order Perciformes Bleeker, 1863

SubOrder Percoidei Nelson, 1994
Family Centrarchidae Bleeker 1859

Genus Lepomis Rafinesque, 1819

\section{Lepomis gibbosus (Linnaeus, 1758)}

- Material Examined: International River Minho, Iberian Peninsula section: Vila Nova de Cerveira municipality (Portugal), 1 adult with $11.5 \mathrm{~cm}$ length (NatMIP-CAPe-0002); 2 adult specimens, being one with $15.5 \mathrm{~cm}$ and another with $9.5 \mathrm{~cm}$ length (NatMIP-CAPe-0008); 3 adult individuals, 13.6, 11.5, $14.2 \mathrm{~cm}$ length (NatMIP-CAPe-0010). Goian (Spain), International Minho River, Iberian Penisula: 1 adult with $12.3 \mathrm{~cm}$ length (NatMIPCAPe-0009). 
- Diagnosis: L. gibbosus is distinguished from the other species of the family Centrarchidae through particular morphological characteristics, such as the smaller operculum (dimensions similar to those of the eyes), dark colouration with lighter points in reddish or orange tones, 3-4 anal spines, 36-37 scales on the side of the body, the posterior-ventral portion of the dorsal and anal area without a dark mark, small mouth, length of the upper jaw is equal to the diameter of the eye (Figure 10a) $[29,30]$.

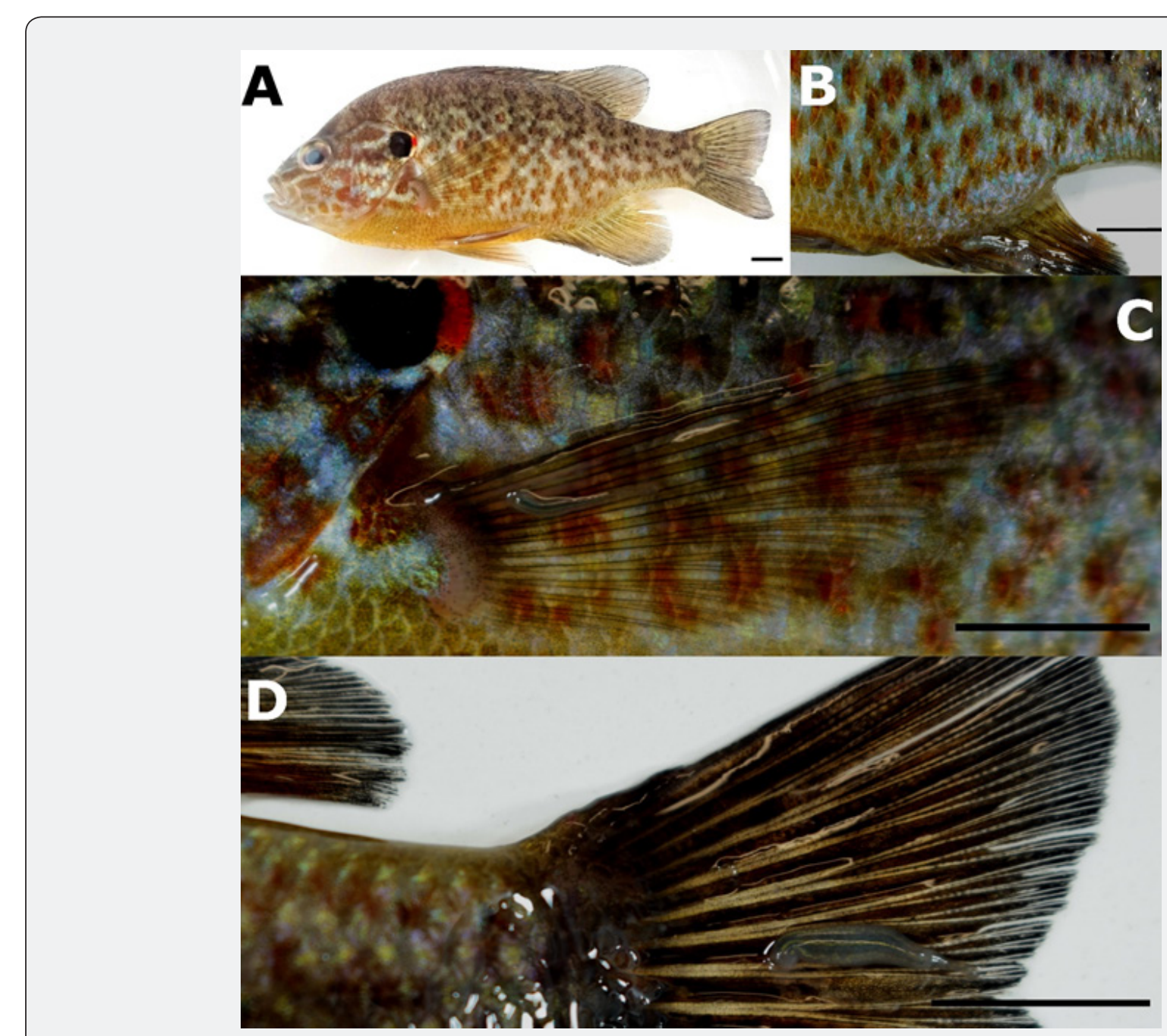

Figure 10: Lepomis gibbosus (Linnaeus, 1758) (NatMIP_CAPe-0010). a) Overview of the species, b) Anal fin, c) Pectoral fin, D) Tail fin with leech ectoparasite attached. Scales: $1 \mathrm{~cm}$.

The ectoparasitic association was detected with the occurrence of leeches belonging to species Myzobdella lugubris Leidy, 1851, which were attached to the L. gibbosus, on anal (Figure 10b), pectoral (Figure 10c), and tail fins (Figure 10c). Fishes did not show signs of perforations or skin ulcerations.

Phylum Annelida Lamarck, 1802
Class Clitellata Michaelsen, 1919
SubClass Hirudinea Savigny, 1822
InfraClass Euhirudinea Lukin, 1956
Order Rhynchobdellida Blanchard, 1894

Family Piscicolidae Johnston, 1865

Genus Myzobdella Leidy, 1851

\section{Myzobdella lugubris Leidy, 1851}

- Material Examined: Marina da Lenta, International Minho River section, Portuguese zone, Iberian Peninsula: 8 individuals (NatMIP-ACRh-0003), 5 individuals (NatMIP-ACRh0004). 
- Diagnosis: This species has an elongate greenish to brownish body, tapering anteriorly and enlarged on posterior region, with a little flattening (Figure 11a, b). Rounded anterior oral sucker with two eyespots (Figure 11c); caudal sucker on posterior end shorter than maximal body width (Figure 11d). Median segments with 12 to 14 annuli. Eversible bursa with an atrium projecting as obtuse cone-shaped, carrying an orifice $[31,32]$.

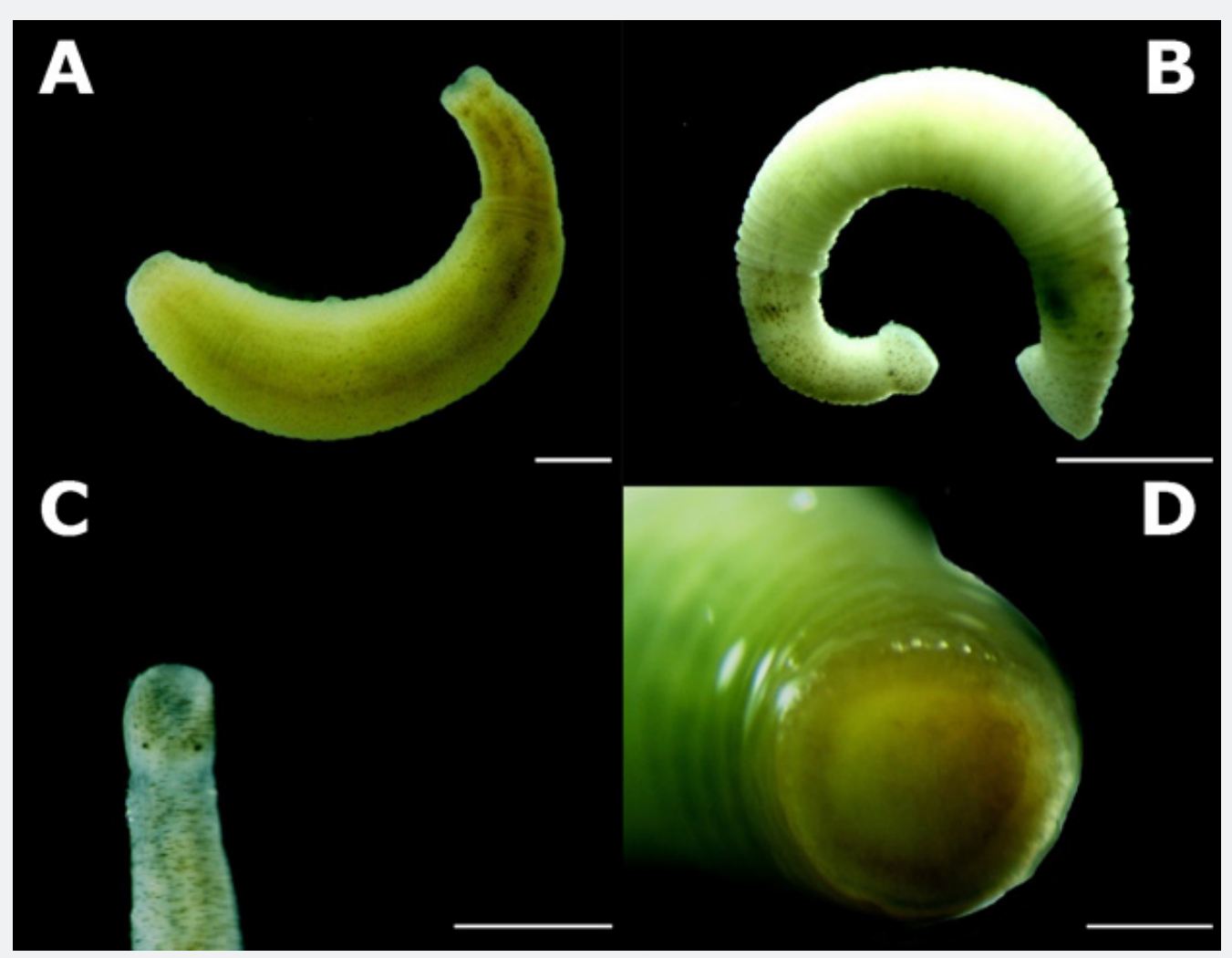

Figure 11: Myzobdella lugubris Leidy, 1851. a) Dorsal view (NatMIP-AHRh-0003), and b) Left lateral view (NatMIP-AHRh-0004), c) Anterior end, with details of two eyespots (NatMIP-AHRh-0003), d) Posterior sucker (NatMIP-AHRh-0003). Scales: 1 mm: a), b), c); 0.5 $\mathrm{mm}: \mathrm{d})$.

This leech species, and its parasitic association with $L$ gibbosus, is now recorded for the first time at the International Minho River, as well as in the European continent. Parasitism association with this pumpkinseed species is considered as the first record in the world.

\section{Discussion}

The Spanish Minho River basin is highly fragmented with dams and the first record of pumpkinseed results from work under the Natura Miño-Minho project carried out in Ourense area dam reservoir ("albufeira", in Portuguese) [11] which mentions their presence since 2000. Although one specimen was captured in the Minho River estuary [8], the present work records its establishment in tidal freshwater wetlands from 2013 onwards. A possible pumpkinseed downward movement may have occurred after its introduction in the Ourense area. The monitoring programme with fyke nets in the Minho River tidal freshwater wetlands began in 2007 [7] on a continuous basis and it was only from July 2013 that regular catches of L. gibbosus occurred.

Individuals live between eight to ten years [9], preferring water with a slow flow or even totally stopped, and it can live in cooler waters than any other sunfish [33]. Temperatures in Minho River suffer an amplitude of $17^{\circ} \mathrm{C}$, from the minimum $\left(8^{\circ} \mathrm{C}\right)$ to the maximum $\left(25^{\circ} \mathrm{C}\right)$, similarly with the results of Antunes et al. [12], being the parameter with the highest variance throughout each year. This reflects the number of captured individuals in the hottest months, when conditions are also likely to favour pumpkinseed sunfish, resulting in higher densities, greater dispersion [34] and breeding activity, which occurs when temperatures are between 13 to $28^{\circ} \mathrm{C}$ [35-37].

Besides this, other parameters were considered, although their impact on data distribution is less significant on L. gibbosus 
population, i.e., $\mathrm{pH}$, conductivity, and salinity, which can be supported by this species up to $18.2 \%$ [30]. The depth of the sampling site was relatively continuous throughout the other years, staying between 3 to $4 \mathrm{~m}$, as well as for salinity (between 0.02 to $0.11 \mathrm{mg} / \mathrm{L}$ ), conductivity $( \pm 140 \mathrm{mS} / \mathrm{cm}$ ), and $\mathrm{pH}$ (between 6 to 8). A specifical analysis was made between 2014 and 2015 when L. gibbosus start to manifest more regularly in fyke nets. This period seems to reveal a more adaptative response to the Marina da Lenta habitat. After 2015, captures were registered regularly every month, showing a possible stabilization of L. gibbosus population. According to Tola and Infiesta [38], the average length reached by the pumpkinseed in America is around $30 \mathrm{~cm}$, while in the Iberian Peninsula, more precisely in the southwest area individuals have lengths between 8 to $15 \mathrm{~cm}$. In the Minho River estuary, the length average increased over time and reached the maximum value of $18.6 \mathrm{~cm}$ in 2016.

Reproduction occurs between the first and third year of life, from April/May until June/August when temperatures reach $16-18^{\circ} \mathrm{C}$. The nests are built and maintained (ventilated and protected) by the males. They guard the nests for a period of 3 to 10 days until the young disperse [39]. According to Fox and Keast [40], the L. gibbosus population reaches maturity early and increases reproducibility in adverse environmental conditions, which results in great phenotypic plasticity due to the accumulated threats through the course of the pumpkinseed life history. Native American populations are more studied because most of the Lepomis genus is particularly important as a game species [41], while European populations received relatively little attention, with limited studies on individuals' growth and age. However, the perception of this species as an invasive species has led to an increased need for knowledge.

Most pumpkinseeds in both native and introduced populations have been found to achieve maturity during their third year of life (age 2 to age 3 increment), and would thus be considered adults $[2,9]$. However, strong juvenile growth and precocious maturity, with a shorter lifespan, appear to be adaptive responses to elevated water temperatures [42]. Indeed, almost all the populations from southern Europe, where the species is considered invasive, exhibit fast juvenile growth and early maturity [43]. In the case of Minho River, the individuals collected and analysed regarding their age structure, between 2014 and 2015, showed superior values of SL for each age group, when compared with other northwestern European populations. These differences resulted mainly from the influence of environmental conditions, such as the temperature that will have a directly proportional correlation and feeding [29].

Although omnivorous, the pumpkinseed tends to feed on prey with greater abundance, with the predation of fish eggs having the most impact on the ecosystem [9]. According to Sadzikowski and Wallace [44], juvenile feeding is mainly composed of microcrustaceans (Cladocera, Copepods) and Chironomidae larvae, while in the adult phase, gastropods are the preferred prey [39]. This type of preference appears to be justified by the morphology of the pharyngeal apparatus and its musculature, specialized in gastropod feeding, which may have resulted from a more primitive benthic feeding $[2,9,29]$. It was found the most important food items to be Diptera and Gastropoda in older individuals while Cladocera dominated in the younger age class.

In Europe, there are very few natural predators, like sander (Sander lucioperca) and the northern pike (Esox lucius) [9], absents in the River Minho, and his biggest competitor is the bluegill (Lepomis macrochirus) also absent in Portugal [10]. In the Minho River, the potential predators are the otter (Lutra lutra) and the cormorant (Phalacrocorax carbo). In addition to being proven that this species has contributed to the decline of native species [9], changing the ecosystem, it is also proven that they are able to take advantage of human activities for their benefit: the construction of dams provide an upstream environment with less flow variation and less current, which facilitates the construction of nests and the nutrients resulting from agriculture guarantee also better food availability [2].

The parasitic performance of M. lugubris with host fishes, adhering on its fins and other skin surfaces has been observed in other studies $[31,32,45,46]$. In Canada (Lake St. Clair), for example, these leeches are found on dorsal, pelvic, pectoral, and caudal fins Percina caprodes (Rafinesque, 1818), and Ameiurus nebulosus (Lesueur, 1819) [47], and attached into to pectoral fins or beneath the inferior jaw of M. salmoides [48]. In North Carolina (USA), intense ulcerations of the tongue and buccal cavity were reported in M. salmoides, associated with species M. lugubris [49].

Some studies mention the species Piscicolaria reducta Meyer, 1940, including, for example, its ectoparasitic association with Lepomis cyanellus Rafinesque, 1819, Lepomis macrochirus Rafinesque, 1819 and Lepomis punctatus (Valenciennes, 1831) [50]. Notwithstanding, this leech species may be the same as M. lugubris, and their sequences' GenBank are probable a misidentification because the phylogenetic tree and consensus tree from Maximum Parsimony and Bayesian Inference indicate $P$. reducta nested within the same clade of M. lugubris [32].

\section{Conclusion}

Pumpkinseeds populational dynamics/characterization is now described for Minho River, at the international section area. The species L. gibbosus, being an invasive organism in the Minho River, provoked changes in the aquatic environment and influenced in local abundance of fish species, such as M. salmoides. The leech species $M$. lugubris is recorded for the first time in European waters; and its parasitic association with L. gibbosus is now noticed as the first record in the world, representing an important parasitic organism on host sunfishes' individuals.

\section{Acknowledgements}

The authors would like to thank the facilities provided by "Aquamuseu do Rio Minho", Vila Nova de Cerveira, Portugal. 
We acknowledge to Mafalda Fernandes, Renata Alves, and Eduardo Martins for collecting specimens for this study. A. Lages acknowledgements the internship funding provided by V.N. Cerveira municipal administration. Special thanks to CIIMAR (Interdisciplinary Centre of Marine and Environmental Research) for supporting D. Costa and N. Gomes by project's contract COOPERMINHO - "Valorização da Produção Piscatória do Rio Minho - Contribuição para a Gestão e Valorização de Produtos da Pesca do Rio Minho - Comunicação e Formação Socioambiental da Comunidade Local para a valorização dos Recursos Piscícolas do Rio Minho", through MAR2020 - Portugal2020 - European Union funding.

\section{References}

1. Joyard J (2019) What is biodiversity? Encyclopedia of the Environment.

2. Almeida D, Almodóvar A, Nicola GG, Elvira B (2008) Feeding tactics and body condition of two introduced populations of pumpkinseed Lepomis gibbosus: taking advantages of human disturbances? Ecology of Freshwater Fish 18(1): 15-23.

3. Mollot G, Pantel JH, Romanuk TN (2017) The Effects of Invasive Species on the Decline in Species Richness: A Global Meta-Analysis, Chapter Two. Advances in Ecological Research 56: 61-83.

4. Cook EJ, Payne RD, Macleod AK, Brown SF (2016) Marine biosecurity: protecting indigenous marine species. Research and Reports in Biodiversity Studies 5: 1-14.

5. Delgado ALSAP (2011) Caracterização Hidrodinâmica E Sedimentar Do Estuário Do Rio Minho (Master Thesis). Universidade do Porto.

6. Santos S, Vilar VJP, Alves P, Boaventura RAR, Botelho C (2013) Water quality in Minho/Miño River (Portugal/Spain). Environ Monit Assess 185(4): 3269-3281.

7. Mota M, Sousa R, Bio A, Araújo J, Braga C, et al. (2014) Seasonal changes in fish assemblages in the River Minho tidal freshwater wetlands, NW of the Iberian Peninsula. International Journal of Limnology 50(3): 185-198.

8. Sousa R, Dias S, Guilhermino L, Antunes C (2008) Minho River tidal freshwater wetlands: threats to faunal biodiversity. Aquatic Biology 3: 237-250.

9. Copp GH, Fox MG, Przybylski M, Godinho FN, Vila-Gispert A (2004) Lifetime growth patterns of pumpkinseed Lepomis gibbosus introduced to Europe, relative to native North American populations. Folia Zool 53(3): 237-254

10. Bhagat Y, Fox M G, Ferreira MT (2006) Morphological differentiation in introduced pumpkinseed Lepomis gibbosus (L.) occupying different habitat zones in Portuguese reservoirs. Journal of Fish Biology 69: 7994.

11. Xunta de Galicia (2011) Estudio poblaciones de peces de los embalses de Albarellos, Cachamuiña, Leboreiro y Edrada. Proyecto Natura MiñoMinho (Report).

12. Antunes C, Araújo MJ, Braga C, Roleira A, Carvalho R, et al. (2012) Valorização dos recursos naturais da bacia hidrográfica

1. do rio Minho. Final report from the project Natura Miño-Minho, Centro interdisciplinar de Investigação Marinha e Ambiental, Universidade do Porto.

13. Coimbra J, Antunes J, Damasceno-Oliveira A, Dias S (2005) Bacia
Hidrográfica do Minho.

14. Knoöpell HA (1970) Food of central Amazonian Fishes. Contribution to the nutrient-ecology of Amazonian rainforest-streams. Amazoniana 2: $257-352$.

15. Campaioli S, Ghetti P, Minelli A, Ruffo S (1997) Manuale per il ricnonoscimento del macroinvertebrati delle acque dolci italiane.

16. Bis B, Kosmala G (2005) Chave de Identificação de Macroinvertebrados Bentónicos de Água Doce. Education and Culture, Project CO.

17. Serra S, Coimbra N, Graça M (2009) Invertebrados de água doce: chave de identificação das principais famílias. Imprensa da Universidade de Coimbra, Coimbra.

18. Secor DH, Dean JM, Laban EH (1992) Otolith removal and preparation for microstructural examination. In: Stevenson D K, Campana S E (eds) Otolith microstructure examination and analysis, Canadian Special Publication of Fisheries and Aquatic Sciences P 117.

19. Albrechtsen K (1968) A Dyeing Technique for Otolith Age Reading. ICES Journal of Marine Science 32(2): 278-280.

20. Havunders T, Hjalti $S$ (1968) A technique for sectioning blue whiting otoliths for age determination. Fiskeridirektoratetts Skrifter, Serie Havundersprkelser 16: 189-193.

21. Panfili J, Pontual H, Troadec H, Wright P (2002) Manual of fish sclerochronology (Ifremer-IR). Brest, France.

22. Regier H (1962) Validation of the Scale Method for Estimating Age and Growth of Bluegills. Transactions of the American Fisheries Society 91(4): 362-374

23. Zeyl J, Love 0, Higgs D (2013) Evaluating gonadosomatic index as an estimator of reproductive condition in the invasive round goby, Neogobius melanostomus. Journal of Great Lakes Research 4(1): 164171.

24. Costa APR, Andrade DR, Vidal Junior MV, Souza G (2005) Indicadores quantitativos da biologia reprodutiva de fêmeas de piau-vermelho no Rio Paraíba do Sul. Pesquisa Agropecuaria Brasileira 40(8): 789-795.

25. Querol M, Querol E, Gomes N (2002) Fator de condição gonadal, índice hepatossomático e recrutamento como indicadores do período de reprodução de Loricariichthys platymetopon (Osteichthyes, Loricariidae), bacia do rio Uruguai médio, sul do Brasil. Iheringia Série Zoologia 92(3): 79-84.

26. Jisr N, Younes G, Sukhun C, El-Dakdouki M (2018) Length-weight relationships and relative condition factor of fish inhabiting the marine area of the Eastern Mediterranean city, Tripoli-Lebanon. The Egyptian Journal of Aquatic Research 44(4): 299-305.

27. Murphy B, Willis D (1996) Fisheries Technique, $2^{\text {nd }}$ edition. American Fisheries Society, Bethesda, Maryland.

28. StatSoft Inc (2007) STATISTICA (data analysis software system).

29. Etnier D, Starnes W (1993) The Fishes of Tennessee. University of Tennessee Press: Tenesse. P. 398.

30. Kottelat M, Freyhof J (2007) Handbook of European freshwater fishes (Kottelat). Berlin, Germany.

31. Sawyer RT, Lawler AR, Overstreet RM (1975) Marine leeches of the eastern United States and the Gulf of Mexico with a key to the species. Journal of Natural History 9: 633-667.

32. Saglam N, Saunders R, Lang S A, Shain D H (2018) Phylogeny and cocoon production in the parasitic leech Myzobdella lugubris Leidy, 1851 (Hirudinidae, Piscicolidae). Acta Parasitologica 63(1): 15-26. 
33. O Hara JJ (1968) Influence of weight and temperature on metabolic rate of sunfish. Ecology 49(1): 159-161.

34. Copp HG, Britton JR, Guo Z, Edmonds-Brown VR, Pegg J, et al. (2017) Trophic consequences of non-native pumpkinseed Lepomis gibbosus for native pond fishes. Biological Invasions 19: 25-41.

35. Wang J (1996) Fishes of the Sacramento-San Joaquin Estuary and Adjacent Waters, California: A Guide to the Early Life Histories. Digital Library Project Berkeley, US.

36. Paulson N, Hatch J (2002) Fishes of Minnesota.

37. Bullock D (2006) Lepomis gibbosus, Animal Diversity Web.

38. Tola J, Infiesta E (2002) Peces continentales de la Peninsula Ibérica. Ediciones Jaguar SA Madrid.

39. Etnier DA (1971) Food of Three Species of Sunfishes (Lepomis, Centrarchidae) and Their Hybrids in Three Minnesota Lakes. Transactions of the American Fisheries Society 100(1): 124-128.

40. Fox MG, Keast A (1991) Effect of overwinter mortality on reproductive life history characteristics of pumpkinseed (Lepomis gibbosus) populations. Canadian Journal of Fisheries and Aquatic Sciences 48 1792-1799.

41. Berra T (2001) Freshwater Fish Distribution. Academic Press, California.

42. Cucherousset J, Copp G, Fox M, Sterud E, Kleef H, et al. (2009) Lifehistory traits and potential invasiveness of introduced pumpkinseed Lepomis gibbosus populations in northwestern Europe. Biological Invasions 11(9): 2171-2180.

43. Copp GH, Fox MG (2007) Growth and life history traits of introduced pumpkinseed (Lepomis gibbosus) in Europe, and the relevance to invasiveness potential. In: Gherardi F (ed) Freshwater bioinvaders: profiles, distribution, and threats. Springer, Berlin, Pp 289-306.

44. Sadzikowski MR, Wallace DC (1976) A Comparison of the Food Habits of Size Classes of Three Sunfishes (Lepomis macrochirus Rafinesque, L. gibbosus (Linnaeus) and L. cyanellus Rafinesque). The American Midland Naturalist 95(1): 220-225.

45. Daniels BA, Sawyer RT (1975) The biology of the leech Myzobdella lugubris infesting blue crabs and catfish. Biological Bulletin 148: 193198.

46. Amin OM (1981) Leeches (Hirudinea) from Wisconsin, and the description of the spermatophore of Placobdella ornate. Transactions of the American Microscopical Society 100: 42-51.

47. Appy RG, Cone DK (1982) Attachment of Myzobdella lugubris (Hirudinea: Piscicolidae) to Logperch, Percina caprodes, and Brown Bullhead, Ictalurus nebulosus. Transactions of the American Microscopical Society 101: 135-141.

48. Troxel DJ (2010) Parasites of Largemouth Bass (Micropterus salmoides) in Northern California. A Thesis Presented to The Faculty of Humboldt State University in Partial Fulfilment of The Requirements for the Degree Master of Science Natural Resources, Fisheries Pp. 59.

49. Noga EJ, Bullis RA, Miller GC (1990) Epidemic oral ulceration in largemouth bass (Micropterus salmoides) associated with the leech Myzobdella lugubris. J Wildl Dis 26(1): 132-134.

50. Price WW, Nadolny JV (1993) Piscicolaria reducta (Hirudinea: Piscicolidae) from Fishes in a Subtropical Florida Stream. Journal of the Helminthological Society of Washington 60(1): 130-134.

\section{Your next submission with Juniper Publishers will reach you the below assets}

- Quality Editorial service

- Swift Peer Review

- Reprints availability

- E-prints Service

- Manuscript Podcast for convenient understanding

- Global attainment for your research

- Manuscript accessibility in different formats ( Pdf, E-pub, Full Text, Audio)

- Unceasing customer service

Track the below URL for one-step submission https://juniperpublishers.com/online-submission.php 